\title{
PENGENDALI BEBAN LISTRIK MENGGUNAKAN HAND PHONE MELALUI MISSCALL
}

\author{
Oleh : \\ Ahmad Bahri Joni Malyan ${ }^{1)}$, Surfa Yondri ${ }^{2)}$ \\ ${ }^{1}$ Jurusan Teknik Komputer Politeknik Negeri Sriwijaya \\ ${ }^{2}$ Jurusan Teknik Elektro Politeknik Negeri Padang \\ bahrijoni@yahoo.co.id ${ }_{2}{ }^{1)}$, surfa_yondri@yahoo.com ${ }^{2)}$
}

\begin{abstract}
An Electric Load Controller is a tool to make easier an implementation of repeated activities such as to turn on and turn off the electric load by using a hand phone as a controller. The controller aims to take into account problems related to control systems and to design a control system that can be implemented in the house hold in case of turning on and off electric loads. A user may turn on and off electric loads from a remote place easily. The design of control, microcontroller, relay, load and rectifier are applied on this research. Furthermore, a hand phone is used for the missed call feature and IC AT89S52 is used on the microcontroller design through BASCOM 8051 programming so as to make missed call feature can be transmitted to a destination number without manually turning off and on electrical devices at home.
\end{abstract}

Keywords : kendali, beban listrik, handphone, misscall mikrokontroller, modem, GSM

\section{PENDAHULUAN}

Kemajuan teknologi semakin berkembang sangat pesat pada kehidupan manusia pada saat ini, khususnya pada bidang Elektronika. Seiring dengan perkembangan zaman, aktivitas manusia semakin meningkat sehingga menyebabkan pekerjaan yang akan dilakukan memakan waktu yang tidak sedikit dan tidak efektif. Terlebih lagi jika pekerjaan itu dilakukan berulang ulang sehingg menjadi tidak effektif.

Teknologi informasi sekarang ini membutuh kecepatan dan ketepatan dan waktu yang singkat dalam melakukan pekerjaannya. Dalam melakukan suatu kendali peralatan elektronik manusia membutuhkan suatu teknologi. Perkembangan teknologi informasi menggunakan handphone selain digunakan sebagai alat komunikasi dapat digunakan kendali peralatan elektronik pada jarak jauh. Pengendalian beban listrik menggunakan handphone ini dihubungkan dengan suatu mikrokontroler. Dengan menggunakan mikrokontroler dalam rangkaian elektroniknya akan menjadikan rangkaian lebih mudah biaya yang dibutuhkan relatif lebih murah.

Pada pengendalian jarak jauh antar pulau dapat dikendali menggunakan handphone melalui misscall yang terdapat pada fasilitas handphone yang dihubungkan menggunakan Mikrokontroler AT89S52 sebagai komponen pengendali menyala dan memadamkan beban listrik sesuai dengan keinginkan. Mikrokontroler AT89S52 dapat bekerja bila programmable read only memory dalam Mikrokontroler tersebut terdapat sebuah 
program yang berupa intruksi-intruksi yang akan digunakan untuk mengeksekusi sistem mikrokontroler. Pada perancangan ini mengaplikasikan Mikrokontroler yang dihubungkan pada rangkaian akan menyalakan atau memadamkan beban listrik melalui pengendalian Mikrokontroller AT89S52. Rangkaian ini dibentuk dengan beberapa komponen utama yaitu rangkaian terpadu Mikrokontroler AT89S52, transistor, relay, lampu.

\section{TINJAUAN PUSTAKA}

\section{Modem Wavecom}

Modem wavecom adalah sebuah modem Global System For Mobile (GSM) yang banyak digunakan sebagai Short Massage Service gateway dengan menggunakan komunikasi serial dengan baudrate 9600bps. Untuk dapat berkomunikasi dengan modem ini ada protocol komunikasi yang digunakan yaitu dengan menggunakan $A T$ Commands yaitu sekumpulan perintah untuk mengontrol modem yang diawali dengan perintah $A T$ (attention) SIM (http://kiswara.com/seputar-modemwavecom-fastrack-67-19).

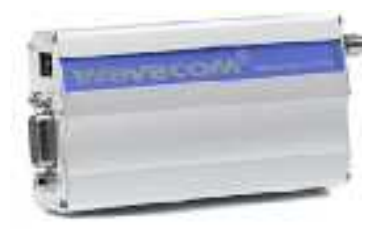

Gambar 1. Modem Wavecom Fastracx

Berikut ini spesifikasi dari Modem wavecom ini:

1. EGSM 900/1800MHz (Band:

Dual-band

EGSM 900/1800 MHz)

2. Supports voice / data / fax / SMS (text

and PDU modes) / GPRS

3. Open AT capable for embedded applications
4. Optional TCP/IP stack permitting

direct

UDP/TCP connectivity and OP3/SMTP/FTP services

5. 15-pin sub-D connector for voice and RS-232 serial interface

6. Fully type-approved dan 3V SIM Interface

7. $25 \mathrm{~mm}$ shorter than M1206B predecessor

8. Serial port shutdown power saving feature

9. Two general-purpose input/output pins built into Molex power

10. Dimensions: 73 × 54 × $25 \mathrm{~mm}$ dan Weight: $82 \mathrm{~g}$

11. Input Voltage: 5.5 to $32 \mathrm{v} \mathrm{DC}$

Modem GSM adalah sebuah perangkat elektronik yang berfungsi sebagai alat pengirim dan penerima pesan SMS. Tergantung dari tipenya, tapi umumnya alat ini berukuran cukup kecil, ukuran sama dengan pesawat telepon seluler GSM. Sebuah modem GSM terdiri dari beberapa bagian, di antaranya adalah lampu indikator, terminal daya, terminal kabel ke komputer, antena dan untuk meletakkan kartu SIM.

\section{Misscall}

Misscall adalah suatu mendia pengiriman data melalaui handphone yang tidak memerlukan biaya karena koneksi hanya memberi tahu bahwa ada seseorang akan menelepon. Dengan media seperti ini diharapkan pengendalian tidak memerlukan biaya.

\section{GSM}

GSM merupakan teknologi seluler yang perkembangannya paling pesat dan mempunyai pasar terbesar di Indonesia. Sistem GSM memiliki keunggulan seperti keluwesan roaming, keamanan data, kualitas sinyal yang tinggi, portabilitas dan kompatibilitas terhadap sistem lain, dan paling banyak digunakan oleh user bergerak. Aplikasi komunikasi 
data dan jaringan internet sepert: World Wide Web (WWW), File Transfer Protocol (FTP), Telnet, Mobile Banking dan aplikasi-aplikasi multimedia berbasis internet akan bisa dijalankan di atas sistem komunikasi bergerak (Lingga, 2006)

Servis telepon mobile pertama kali yang menggunakan koneksi duplek dimulai pada tahun 1946 sebagai servis telepon dalam mobil. Masalah yang terdapat pada sistem ini yaitu peralatan yang digunakan sangat besar dan berat, area servis kecil karena hanya menggunakan satu antena transmisi (sistem single cell). Hasilnya adalah Kapasitas terbatas, peralatan yang mahal dan kualitas servis yang rendah (Rachman. 2006).

Dengan berkembangnya teknologi baru semikonduktor, dioda, transistor, Integrated Circuit (IC), mikroprosesor yang menghasilkan switching otomatis, bentuk perangkat yang lebih praktis dan murah, pada tahun 1970an peralatan komunikasi mulai berkembang, namun masih ada satu masalah yaitu Sistem single cell yang mempunyai kapasitas terbatas (Rachman. 2006).
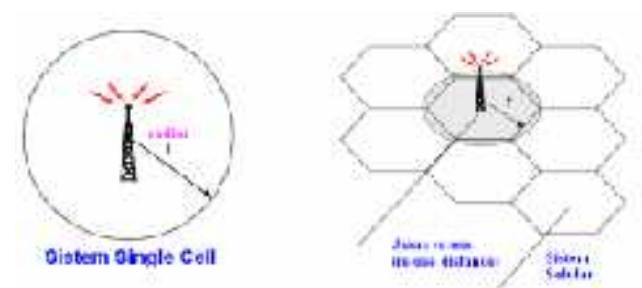

Gambar 2 Sistem Single Cell

Koneksi antar cell sering disebut juga sebagai hand over (HO), dimana hand over ialah proses perubahan pelayanan/peng-handle-an sebuah Mobile Station (MS) dari suatu cell ke satu cell lain dikarenakan adanya pergerakan MS yang menjauhi cell awal dan mendekati cell baru. hand over hanya terjadi pada saat MS sedang melakukan hubungan dengan MS lain. Kalau perubahan peng-hadle-an terjadi pada saat MS sedang bebas (tidak melakukan call) maka proses itu disebut location update, bukan hand over (Rachman. 2006).

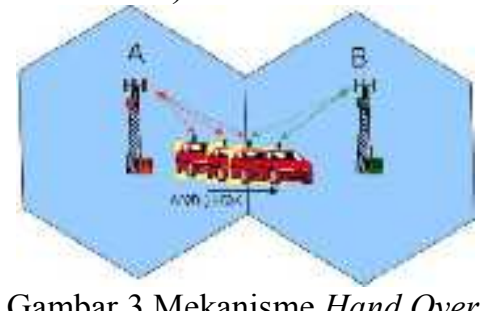

Gambar 3 Mekanisme Hand Over

Mekanisme Hand over dapat dibagi menjadi 2, yaitu :

- Make Before Break, pada mekanisme ini, sebelum MS terhubung dan dilayani oleh cell yang baru, maka hubungan dengan cell lama tidak akan diputus. Hubungan dengan cell lama hanya akan diputus bila hubungan dengan cell baru sudah dapat dilakukan. Mekanisme ini dapat dilihat pada gambar di atas. Mekanisme ini dikenal juga dengan sebutan Soft Hand Over.

- Break Before Make, pada mekanisme ini, MS akan memutuskan hubungan dengan cell lama walupun hubungan dengan cell baru belum tercapai. Akibatnya akan ada suatu periode waktu yang singkat dimana MS tidak dilayani oleh cell manapun. User akan merasakan akibat dari hal ini dalam bentuk terputusnya pembicaraanya sesaat.

Hand Over bisa dibagi menjadi tiga jenis, yaitu :

1. Hand Over Intra BSC, yaitu perpindahan peng-handle-an suatu MS dari satu cell ke cell lain, dimana kedua cell tersebut terhubung ke satu BSC yang sama.

2. Hand Over Inter BSC, yaitu perpindahan peng-handle-an suatu MS dari satu cell ke cell lain, dimana kedua cell tersebut terhubung ke dua BSC yang berbeda, tapi masih dalam satu MSC yang sama.

3. Hand Over Inter MSC, yaitu perpindahan peng-handle-an suatu 
MS dari satu cell ke cell lain, dimana kedua cell tersebut terhubung ke dua BSC yang berbeda, dan masingmasing BSC terhubung ke MSC yang berbeda juga.

\section{Mikrokontroller AT89S52}

Mikrokontroller

AT89S52

merupakan mikrokontroler CMOS 8 bit tipe $\mathrm{S}$ yang memiliki performa tinggi dengan konsumsi daya rendah dan memiliki sistem pemograman kembali (Programmable and Erasebla Read Only Memory) dengan kemampuan lebih kurang 1000 kali dapat diprogram ulang (Putra,2004).

Beberapa Keistimewaan yang dimiliki mikrokontroller ini antara lain adalah:

- Frekwensi antara $0 \mathrm{~Hz}$ sampai 24 $\mathrm{MHz}$.

- 8 Kbyte internal ROM.

- 256 bytes internal RAM.

- 32 saluran I/O.

- Tiga buah timer/conter 16 bit.

- Delapan buah sumber interupsi.

- Komunikasi serial duplex.

Pada arsitektur AT89S52 terlihat jelas bahwa terdapat empat port untuk I/O data dan tersedia pula akumulator, register, RAM, stack pointer, Aritmetic Logic Unit (ALU) Pengunci (latch), dan rangkaian osilasi yang membuat AT89S52 dapat beroperasi dalam satu chip. Bagian-bagian dari mikrokontroler tersebut digambarkan dalam bentuk blok diagram gambar 4 .

\section{Konfigurasi Pin mikrokontroler AT89S52}

Mikrokontroller AT89S52 memiliki 40 pin, dimana masing-masing pin pada mikrokontroler tersebut mempunyai fungsi tersendiri. Dengan mengetahui fungsi masing-masing pin, perancangan aplikasi mikrokontroler AT89S52 akan lebih mudah. Dari ke 40 pin yang dimiliki oleh mikrokontroler AT89S52,
32 pin digunakan untuk keperluan port pararel, setiap port terdiri dari 8 pin, sehingga terdapat 4 port, yaitu port 0 , port 1 , port, 2, port 3. Susunan masing masing pin dapat dilihat pada gambar 5 (Khairurrijal, 2004).

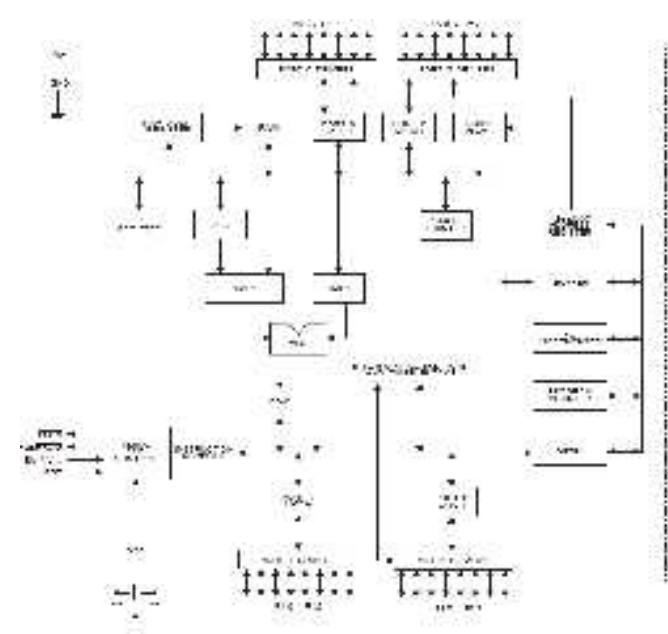

Gambar 4. Arsitektur Mikrokontroler AT89S5

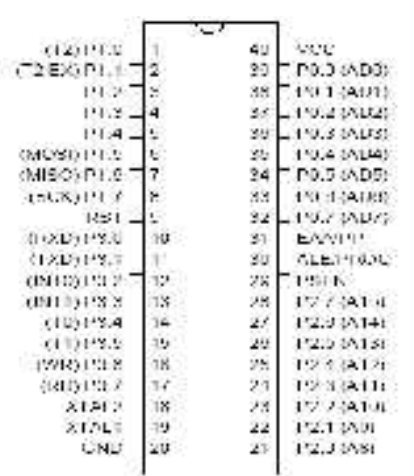

Gambar 5. Mikrokontroler AT89S52

\section{LCD}

Layar LCD merupakan media penampil data yang sangat efektif dalam suatu sistem elektronika. Agar sebuah pesan atau gambar dapat tampil pada layar LCD, diperlukan sebuah rangkaian pengatur scanning dan pembangkit tegangan sinus.LCD matrik memiliki konfigurasi 16 karakter dan 2 baris dengan setiap karakternya dibentuk oleh 8 baris pixel dan 5 kolom pixel. Pada modul LCD telah terdapat suatu driver 
yang berfungsi untuk mengendalikan tampilan pada layar LCD. Modul LCD dilengkapi terminal keluaran yang digunakan sebagai jalur komunikasi dengan mikrokontroller. LCD mengirim data penerima data 4 bit atau 8 bit dari perangkat prossesor kemudian data tersebut diproses dan ditampilkan berupa titik- titik yang membentuk karakter atau huruf (Heryanto,2008).

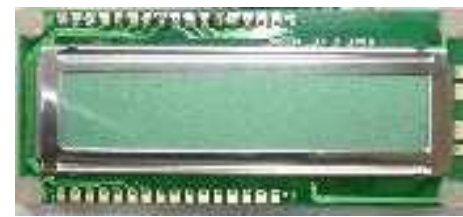

Gambar 6 Modul LCD Karakter

\section{METODE PENELITIAN}

Di dalam penelitian ini, proses perancangan dilakukan beberapa cara, antara lain:

- Metode literatur/ dokumentasi

Mencari dan mengumpulkan data-data atau literaturliteratur yang dapat digunakan untuk melengkapi penulisann, baik yang berasal dari buku bacaan, internet, maupun sumber-sumber lain yang berhubungan dengan materi yang akan dibahasa.

- Metode observasi

Metode pengumpulan data ini dilakukan dengan cara melakukan pengamatan dan pelaksanaan kerja dari hasil pengukuran terhadap perancangan dan pembuatan alat.

\section{HASIL DAN PEMBAHASAN}

Pada bagian ini penulis akan membahas mengenai prinsip kerja rangkaian kendali beban listrik (lampu) menggunakan handphone dengan memanfaatkan BASCOM 8051 sebagai data sensor yang pembanding untuk mengaktifkan beban lampu tersebut dengan kode karakter yang telah ditentukan. Pembahasan ini terdiri dari rangkaian sistem minimum mikrokontroler AT8952, program bahasa basic.

\section{Metode Pengujian dan Pengukuran}

Untuk mempermudah pengambilan data, maka digunakan metode titik uji pengukuran. Dengan metode ini maka akan dilakukan pengukuran titik-titik terpenting dalam rangkaian kendali lampu menggunakan handphone sehingga akan diperoleh data yang akurat untuk digunakan menganalisa cara kerja rangkaian.

\section{Rangkaian Pengujian dan Pengukuran}

Pengujian untuk kendali lampu menggunakan handphone dilakukan dibeberapa titik pengujian, yaitu pada masukan di port mikrokontroler AT8952 pada relay, keluaran pada tegangan lampu 220 Vac, komunikasi mikrokontroler AT8952 dengan handphone pada pin TX dan RX data.

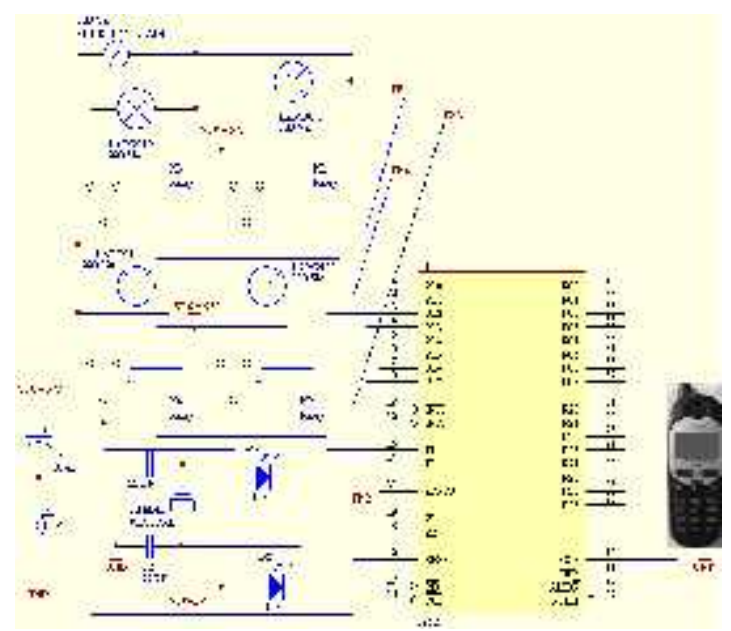




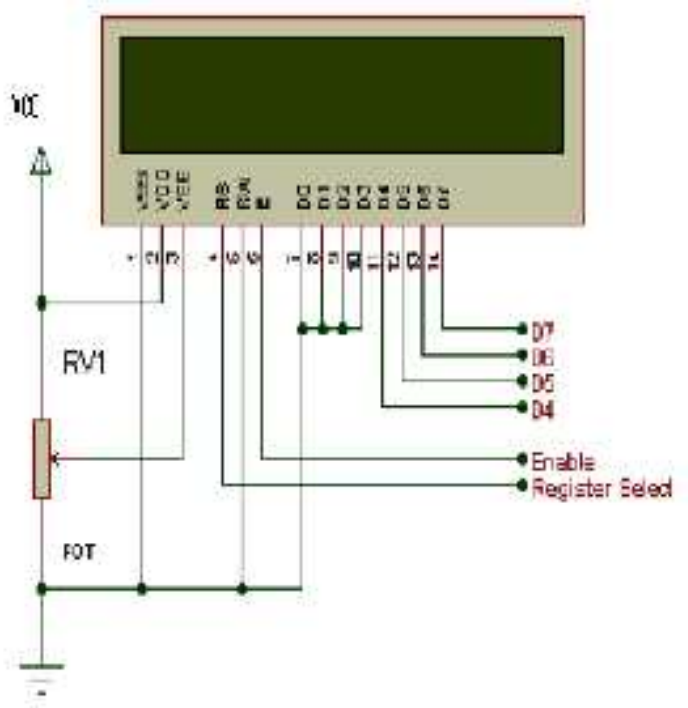

Gambar 7. Rangkaian Lengkap Pengujian

\section{Langkah-langkah Pengukuran}

Pengujian dilakukan, untuk mengurangi kesalahan yang terjadi pada saat pengukuran dengan langkah-langkah sebagai berikut:

- Menyiapkan peralatan yang diperlukan dalam melakukan pengukuran.

- Periksa apakah semua peralatan yang digunakan untuk pengukuran dalam kondisi baik.

- Periksa semua rangkaian yang terhubung dengan mikronkontroler AT8952 dan handphone.

- Mengaktifkan switch On/Off 220 Vac dan memastikan sudah terhubung sumber tegangan $220 \mathrm{Vac}$ selanjutnya mulai melakukan pengukuran.

- Hubungkan multimeter ke titik pengujian yang ada pada rangkaian, catat hasil pengukuran yang didapat.

- Bila pengukuran yang dilakukan telah selesai maka semua peralatan dalam kondisi di padamkan.

\section{Hasil Pengujian}

Dari hasil pengukuran maka diperoleh data yang dapat dijadikan pedoman dalam menganalisa, serta membantu memudahkan dalam mencari kesalahan apabila gangguan pada rangkaian kendali lampu menggunakan handphone tersebut. Dalam pengukuran kendali lampu menggunakan handphone ini dibagi menjadi 2 bagian yaitu:

Tabel 1. Pengujian kendali lampu kondisi ON dengan misscall

\begin{tabular}{|c|c|c|c|c|c|}
\hline No. & $\begin{array}{l}\text { Nomor Hanphone } \\
\text { Pengirim dan } \\
\text { Misscall } \\
\end{array}$ & $\begin{array}{c}\text { Output } \\
\text { P1.2 } \\
\text { (Relay 1) } \\
\end{array}$ & $\begin{array}{c}\text { Output } \\
\text { P1.3 } \\
\text { (Relay 2) } \\
\end{array}$ & $\begin{array}{c}\text { Output } \\
\text { P1.7 } \\
\text { (Relay 3) } \\
\end{array}$ & $\begin{array}{l}\text { Output } \\
\text { P3.0 } \\
\text { (Relay 4) } \\
\end{array}$ \\
\hline 1. & 6281958481593 & $\begin{array}{c}5 \mathrm{~V} \\
\text { (Lampu } 1 \\
\text { ON) }\end{array}$ & $\begin{array}{c}5 \mathrm{~V} \\
\text { (Lampu } 2 \\
\text { OFF) }\end{array}$ & $\begin{array}{c}5 \mathrm{~V} \\
\text { (Lampu } 3 \\
\text { OFF) }\end{array}$ & $\begin{array}{c}5 \mathrm{~V} \\
\text { (Lampu } 4 \\
\text { OFF) }\end{array}$ \\
\hline 2. & 6281958481593 & $\begin{array}{c}5 \mathrm{~V} \\
\text { (Lampu } 1 \\
\text { OFF) }\end{array}$ & $\begin{array}{c}5 \mathrm{~V} \\
\text { (Lampu } 2 \\
\text { ON) }\end{array}$ & $\begin{array}{c}5 \mathrm{~V} \\
\text { (Lampu } 3 \\
\text { OFF) }\end{array}$ & $\begin{array}{c}5 \mathrm{~V} \\
\text { (Lampu } 4 \\
\text { OFF) }\end{array}$ \\
\hline 3. & 6281958481593 & $\begin{array}{c}5 \mathrm{~V} \\
\text { (Lampu } 1 \\
\text { OFF) }\end{array}$ & $\begin{array}{c}5 \mathrm{~V} \\
\text { (Lampu } 2 \\
\text { OFF) }\end{array}$ & $\begin{array}{c}5 \mathrm{~V} \\
\text { (Lampu } 3 \\
\text { ON) }\end{array}$ & $\begin{array}{c}5 \mathrm{~V} \\
\text { (Lampu } 4 \\
\text { OFF) }\end{array}$ \\
\hline 4. & 6281958481593 & $\begin{array}{c}5 \mathrm{~V} \\
\text { (Lampu } 1 \\
\text { OFF) }\end{array}$ & $\begin{array}{c}5 \mathrm{~V} \\
\text { (Lampu } 2 \\
\text { OFF) }\end{array}$ & $\begin{array}{c}5 \mathrm{~V} \\
\text { (Lampu } 3 \\
\text { OFF) }\end{array}$ & $\begin{array}{c}5 \mathrm{~V} \\
\text { (Lampu } 4 \\
\text { ON) }\end{array}$ \\
\hline
\end{tabular}

Tabel 2. Pengujian kendali lampu kondisi OFF dengan misscall

\begin{tabular}{|c|c|c|c|c|c|}
\hline No. & $\begin{array}{c}\text { Nomor Hanphone } \\
\text { Pengirim dan } \\
\text { Misscall }\end{array}$ & $\begin{array}{c}\text { Output } \\
\text { P1.2 } \\
\text { (Relay 1) }\end{array}$ & $\begin{array}{c}\text { Output } \\
\text { P1.3 } \\
\text { (Relay 2) }\end{array}$ & $\begin{array}{c}\text { Output } \\
\text { P1.7 } \\
\text { (Relay 3) }\end{array}$ & $\begin{array}{c}\text { Output } \\
\text { P3.0 } \\
\text { (Relay 4) }\end{array}$ \\
\hline 1. & & $\begin{array}{c}5 \mathrm{~V} \\
\text { (Lampu 1 } \\
\text { OFF) }\end{array}$ & $\begin{array}{c}5 \mathrm{~V} \\
\text { (Lampu 2 } \\
\text { OFF) }\end{array}$ & $\begin{array}{c}5 \mathrm{~V} \\
\text { (Lampu 3 } \\
\text { OFF) }\end{array}$ & $\begin{array}{c}5 \mathrm{~V} \\
\text { (Lampu 4 } \\
\text { OFF) }\end{array}$ \\
& 6281958481593 & & & \\
\hline
\end{tabular}

Program Basic Mikrokontroler

\$regfile $=$ "8052.dat"

\$crystal $=11059200$

\$baud $=9600$

\$large

Config Lcdpin $=$ Pin , Db4 $=$ P2.0, Db5 $=$ P2.1,

$\mathrm{Db} 6=\mathrm{P} 2.2, \mathrm{Db} 7=\mathrm{P} 2.3, \mathrm{E}=\mathrm{P} 2.4, \mathrm{Rs}=\mathrm{P} 2.5$

'----------------deklarasi variabel

Deflcdchar 0, 32, 32, 28, 31, 31, 31, 28, 32

' replace? with number (0-7)

Dim U As Byte, Isi(6) As Byte

Dim No(14) As Byte, X As Byte

Dim Nomer As String * 4

Dim A As Byte, Kode As String * 5

Dim N As String * 9

Dim Isisms As String * 16

Cursor Off

Buzer Alias P0.0 
Lampu1 Alias P1.2

Lampu2 Alias P1.3

Lampu3 Alias P1.7

Lampu4 Alias P3.0

Tombol Alias P0.1

'-------------------kondisi mula---------------------

$\mathrm{P} 1=\& \mathrm{~h} 00$

Cls

Print "AT+CNMI=2, 1, 2,0,0"

Print "AT + CLIP $=1$ "

'-----------------greeting-

Locate 1, 1

Lcd "Loading"

Locate 2, 1

For $\mathrm{X}=1$ To 16

Lcd $\operatorname{Chr}(0)$

Wait 1

Next

Awal:

Do

Cls

Lcd "System Ready"

Do

'Wait 1

A $=\operatorname{Inkey()}$

Loop Until A $=$ "R"

'Or A = "+"

If $\mathrm{A}=$ "R" Then GoSub Validasi_nomor

If Nomer $=$ "9353" Or Nomer $=" 1593 "$ Then

Wait 4

GoTo Alarm aktif

Else

GoTo Awal

End If

Loop

Alarm_aktif:

GoSub terima_miscall_aktif

Aktif:

Cls

Locate 2, 1

Lcd "Alarm aktif"

Do

Locate 1, 1

Lcd "Standby"

If Lampu1 = 1 Then

Locate 1,1

Lcd "Ada beban listrik di ON"

Wait 1

GoSub miscall ganggu

GoTo Calling

End If

$\mathrm{A}=\operatorname{Inkey}()$
Loop Until A = "R"

GoSub Validasi nomor

If Nomer $=$ "9359" Or Nomer $=$ "1593" Then

Cls

Lcd "alarm deaktif"

Lampu $1=0$

Lampu2 $=0$

Lampu3 $=0$

Lampu $4=0$

Wait 3

GoSub Terima_miscall_deaktif

Else

GoTo Aktif

End If

Wait 4

GoTo Awal

Calling:

Cls

Print "ATE0"

Wait 1

Locate 1,1

Lcd "caliing...."

Print "ATD +6281958481593;"

Wait 15

Print "ATH"

Locate 1,1

Lcd "Aktif lampu"

Wait 3

Do

Buzer $=1$

Waitms 100

Buzer $=0$

Wait 1

Loop Until Tombol $=0$

GoTo Awal

Validasi_nomor:

Do

$\mathrm{A}=$ Waitkey ()

Loop Until A = "6"

For $U=1$ To 12

$\mathrm{No}(\mathrm{U})=$ Waitkey ()

Next

Locate 1,1

Lcd "+6"

For $\mathrm{U}=1$ To 12

Lcd Chr(No(U))

Next

Nomer $=" "$

For $\mathrm{U}=9$ To 12

Nomer $=$ Nomer $+\mathrm{Chr}(\mathrm{No}(\mathrm{U}))$

Next 


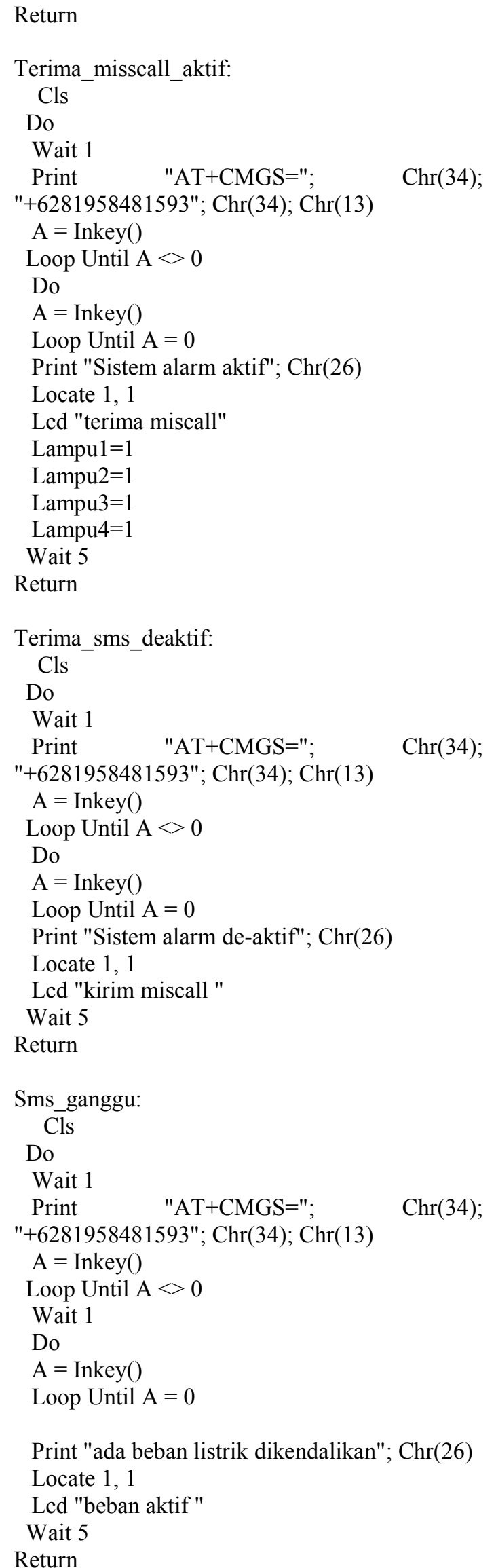

Hasil Simulasi BASCOM 8051 Pada Kendali lampu menggunakan Handphone

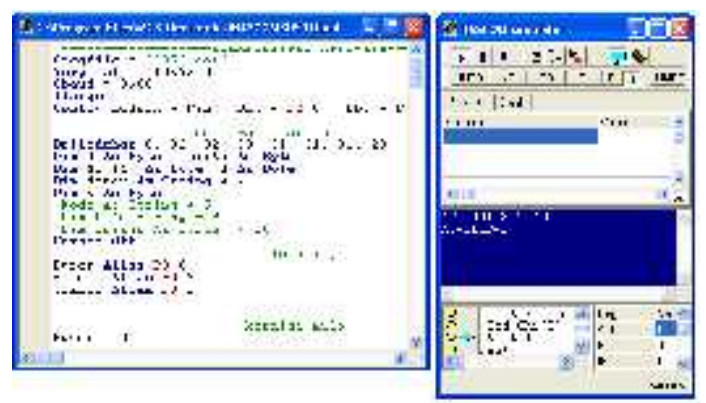

Gambar 9. Simulasi Program menggunakan BASCOM 8051

\section{Pembasan}

Berdasarkan hasil pengukuran yang telah dilakukan pada tabel 3. Pengukuran titik uji keluaran Port 1.3 di TP1, titik uji keluaran basis Port 3.7 di TP2, titik uji keluaran Port 1.7 di TP3 dan titik uji keluaran basis Port $1.2 \mathrm{TP} 4$ saat menerima misscall untuk keempat (4) lampu kondisis ON tersebut.

pada tabel 4. Pengukuran titik uji keluaran Port 1.3 di TP1, titik uji keluaran basis Port 3.7 di TP2, titik uji keluaran Port 1.7 di TP3 dan titik uji keluaran basis Port 1.2 TP 4 saat menerima misscall untuk keempat (4) lampu kondisis OFF tersebut.

\section{Pembahasan pada tabel 3}

Bila handphone pengirim misscall satu kali maka data yang diterima diterjemahkan ke dalam format PDU kemudian apakah nomor handphone tadi sudah sama dengan yang terdapat didalam prograram basic tersebut, bila sama maka pada port 1.2 akan mengeluarkan logika 1 sehingga akan menyalakan lampu $1(\mathrm{ON})$.

Bila handphone pengirim misscall dua kali maka data yang diterima diterjemahkan ke dalam format PDU kemudian apakah nomor handphone tadi sudah sama dengan yang terdapat didalam prograram basic tersebut, bila sama maka pada port 1.3 akan 
mengeluarkan logika 1 sehingga akan menyalakan lampu $2(\mathrm{ON})$.

Bila handphone pengirim misscall tiga kali maka data yang diterima diterjemahkan ke dalam format PDU kemudian apakah nomor handphone tadi sudah sama dengan yang terdapat didalam prograram basic tersebut, bila sama maka pada port 1.7 akan mengeluarkan logika 1 sehingga akan menyalakan lampu $3(\mathrm{ON})$.

Bila handphone pengirim misscall satu kali maka data yang diterima diterjemahkan ke dalam format PDU kemudian apakah nomor handphone tadi sudah sama dengan yang terdapat didalam prograram basic tersebut, bila sama maka pada port 3.0 akan mengeluarkan logika 1 sehingga akan menyalakan lampu $4(\mathrm{ON})$.

\section{Pembahasan pada tabel 4}

Bila handphone pengirim misscall kelima kali maka data yang diterima diterjemahkan ke dalam format PDU kemudian apakah nomor handphone tadi sudah sama dengan yang terdapat didalam prograram basic tersebut, bila sama maka pada port 3.0 akan mengeluarkan logika 0 sehingga akan padam lampu1,2,3 dan 4 (OFF).

Berdasarkan pembahasan di atas, maka dapat diambil kesimpulan sebagai berikut:

Pengendali lampu melalui handphone mengatur ON/ OFF lampu sesuai dengan misscall yang telah ditentukan di program.

\section{Kesimpulan}

Pengendalian beban listrik menggunakan lampu ON/OFF dalam pembuatan program harus mengetahui format protocol data unit agar dalam melakukan miscall ke handphone dapat terjemahan atau dibaca Mikrokontroler AT8952 yang terhubung dengan handphone.

\section{Saran}

Untuk penelitian lebih lanjut disarankan agar dapat digunakan sebagai komunikasi dua arah (duplex) pada mikrokontroler AT8952 maupun handphone dalam melakukan pengendaliannya.

\section{DAFTAR PUSTAKA}

Heryanto, Ary. 2008. Pemrograman Bahasa C un tuk Mikrokontroler ATMega 8535. Andi. Yogyakarta

Khairurrijal. 2004. Teori dan Praktek Mikrokontroler MCS-51, Institut Teknologi Bandung.

Lingga, $\quad 2006$. Mikrokontroler AVR Seri ATMega 8535 Simulasi dan Aplikasi. Andi. Yogyakarta

Putra, Agfianto Eko, 2004, Belajar Mikrokontroler AT89C51/52/55. Gava Media. jogyakarta.

Rachman. 2006. Aplikasi Teleakses Perangkat Bergerak. ANDI. Yogyakarta

\section{http://kiswara.com/seputar-modem-} wavecom-fastrack-67-19. 
ISSN :2085-6989 